\title{
Successful Clipping of a Large Fusiform Aneurysm in the Basilar Artery Using an Endovascular Technique: Report of a Subarachnoid Hemorrhage Case
}

\author{
Hirofumi Oyama, M.D., Kenichi HatToRI, M.D., Akira Kito, M.D., \\ Hideki MaKI, M.D., and Kuniaki TANAHASHI, M.D.
}

Department of Neurosurgery, Ogaki Municipal Hospital, Ogaki, Gifu, Japan

\begin{abstract}
Summary: An 80-year-old male presented with a subarachnoid hemorrhage of Hunt and Kosnik Grade IV. Cerebral angiography revealed a large eccentric fusiform aneurysm arising from the lower portion of the basilar artery just distal to the right anterior inferior cerebellar artery. We decided to surgically treat the ruptured basilar artery aneurysm in the acute stage via a right retromastoid suboccipital approach. Before the operation, we guided a balloon catheter into the left vertebral and right carotid arteries. Intraoperatively, we applied a temporary clip to the right vertebral artery. After exposing the aneurysm, we temporarily inflated the occlusion balloon within the left vertebral and right internal carotid arteries. After suction decompression from the left vertebral artery, we used Sugita's long clip to clip the neck parallel to the basilar trunk. Bradycardia occurred, but the heart rhythm recovered immediately after the recanalization of these arteries. Intraoperative digital subtraction angiography showed obliteration of the aneurysm and preservation of basilar artery patency. The patient gradually recovered consciousness after being in a comatose state for 10 hours after surgery. It is possible to directly clip a large basilar trunk aneurysm. The clipping tends to be done in the same direction as the operative approach. Therefore, the operative approach should be parallel to and should preserve the basilar artery. The intraoperative endovascular technique (using temporary balloon occlusion) and intraoperative digital subtraction angiography can contribute to gaining proximal artery control and verifying basilar artery patency. Clipping is much easier when using suction decompression. However, temporary balloon occlusion should be done as quickly as possible.
\end{abstract}

\section{Introduction}

The treatment of a large fusiform aneurysm of the basilar artery is difficult and controversial. ${ }^{17 / 8}$ We report the successful clipping of a large fusiform basilar trunk aneurysm that presented as a subarachnoid hemorrhage.

\author{
Key words: \\ - fusiform aneurysm \\ - basilar artery \\ - subarachnoid hemorrhage \\ - suction decompression \\ - intraoperative angiography
}

Surg Cereb Stroke

(Jpn) 38: 266-270, 2010

Department of Neurosurgery, Ogaki Municipal Hospital (Received August 3, 2009) (Admitted November 26, 2009)[Address correspondence: Hirofumi Oyama, M.D., Department of Neurosurgery, Ogaki Municipal Hospital, 4-86 Minamikawamachi, Ogaki, Gifu, 503-8502, Japan] 
ness. Computed tomography showed a thick subarachnoid hemorrhage (Fisher Group III) with a collective aneurysm mass in the right cerebello-pontine angle. Cerebral angiography revealed a large eccentric fusiform aneurysm arising from the lower portion of the basilar artery just distal to the right anterior inferior cerebellar artery (Fig. 1). The bleb, which was believed to be the rupture point, was in close proximity to the right petrous bone. The left internal carotid artery was occluded and a collateral flow (via anterior communicating and left posterior communicating arteries) supplied this region. His preoperative Glasgow Coma Scale was 12 points (E2V4M6). He had intact cranial nerve function and no paresis in his extremities.

We decided to treat the aneurysm surgically 3 days after the onset of symptoms (Fig. 3A). We used the Seldinger technique preoperatively to guide a balloon catheter into the left vertebral and right carotid arteries for proximal and distal vascular control (Fig. 2A). The operation was performed in the park bench position using a right paramedian incision and dorsolateral suboccipital craniotomy. We did not perform a petro-

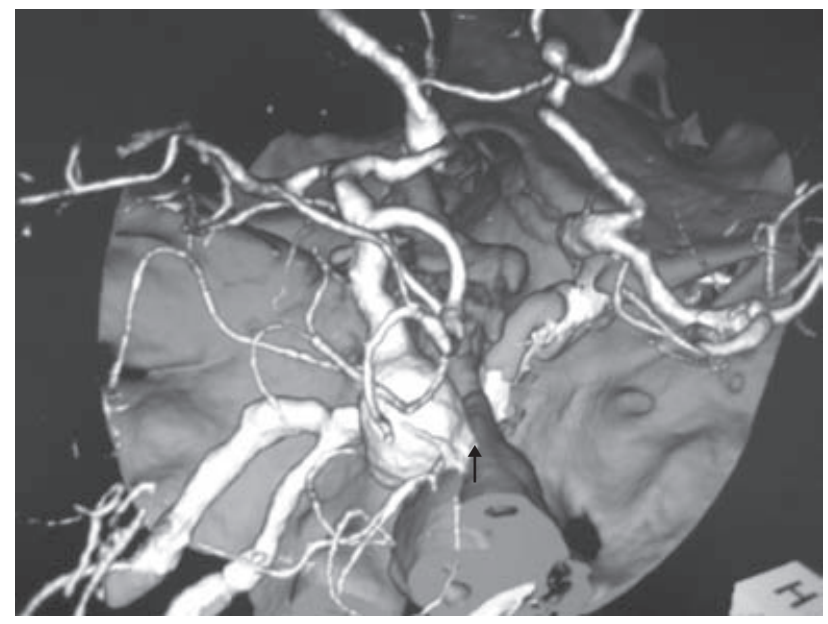

Fig. 1 Preoperative three-dimensional computed tomography scan. Computed tomography angiography shows a large fusiform aneurysm arising from the lower portion of the basilar artery just distal to the right anterior inferior cerebellar artery. The bleb (denoted by an up arrow [ $\uparrow$ ]) is believed to be the rupture point and is in close proximity to the right petrous bone. The left internal carotid artery is occluded on the proximal side but a collateral flow supplies it via anterior communicating and left posterior communicating arteries.

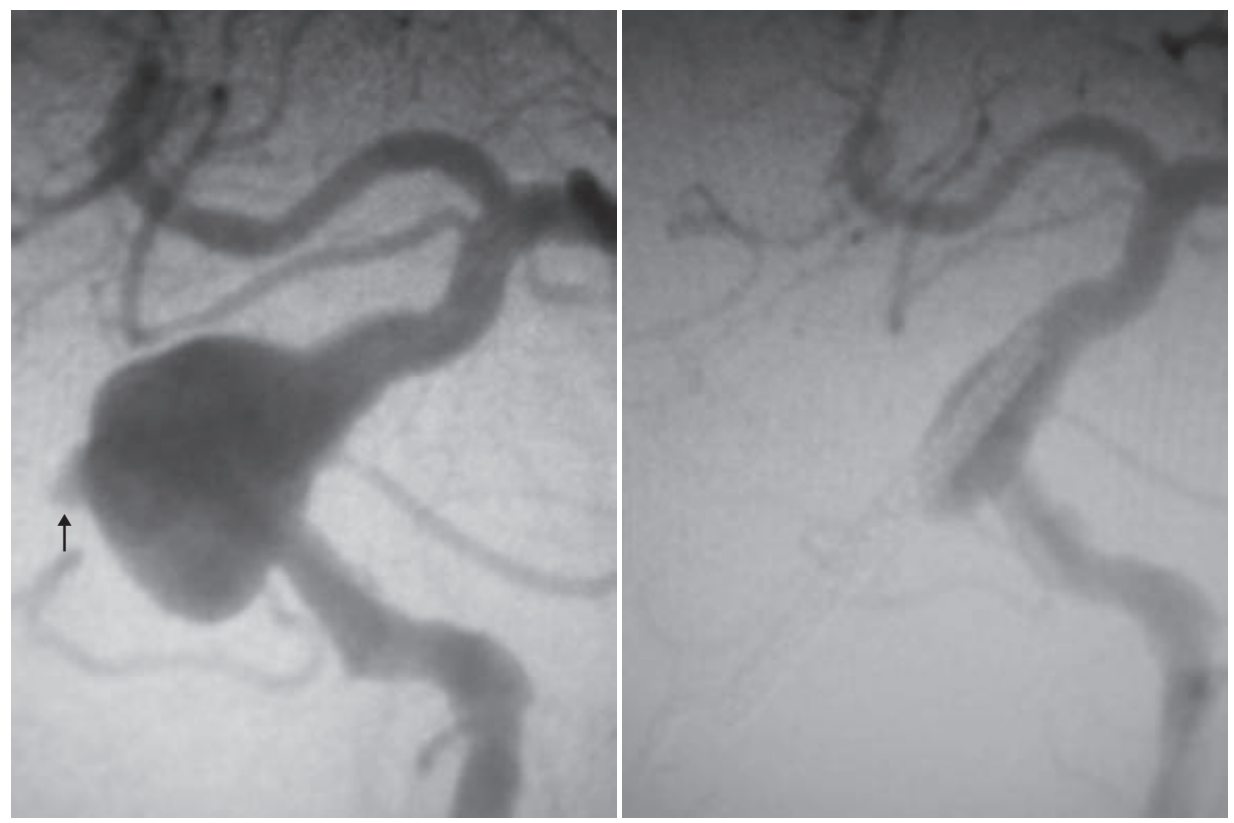

Fig. 2 A: Preoperative left vertebral angiography showing the anteroposterior view. Cerebral angiography shows a large fusiform aneurysm arising from the lower portion of the basilar artery just distal to the right anterior inferior cerebellar artery. The bleb (denoted by an up arrow [ $\uparrow]$ ) is believed to be the rupture point and is in close proximity to the right petrous bone.

B: Intraoperative left vertebral angiography showing the anteroposterior view. Digital subtraction angiography performed just after the clipping, shows obliteration of the aneurysm and preservation of basilar artery patency. 

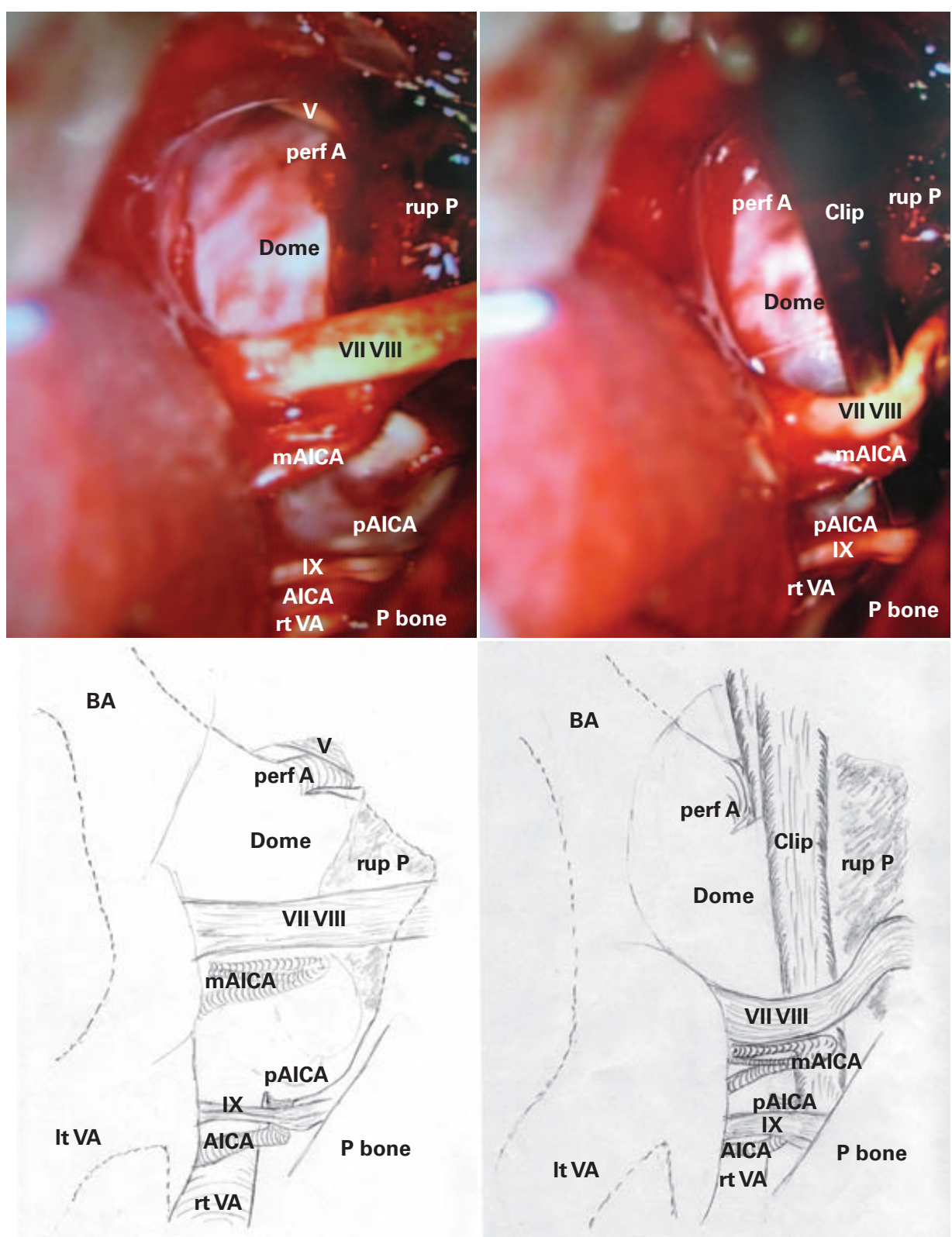

Fig. 3 A: Intraoperative microscopic view and schematic illustration of the right side before clipping. The aneurysmal dome is between the right trigeminal and ninth nerves. The rupture point is in close contact with the right petrous bone.

Abbreviations: AICA, anterior inferior cerebellar artery; BA, basilar artery hidden under the right cerebellar hemisphere and brain stem; Dome, aneurysmal dome including the basilar artery; IX, ninth nerve; It VA, left vertebral artery hidden under the right cerebellar hemisphere and brain stem; mAICA, meatal portion of the anterior inferior cerebellar artery; pAICA, proximal portion of anterior inferior cerebellar artery; $\mathrm{P}$ bone, petrous bone; perf $\mathrm{A}$, perforating artery; rt VA, right vertebral artery; rup $\mathrm{P}$, rupture point; $\mathrm{V}$, fifth nerve; VII VIII; seventh and eighth nerve complex.

B: Intraoperative microscopic view and schematic illustration of the right side during clipping. The clipping was performed between the perforating and anterior inferior cerebellar arteries using Sugita's long clip.

Abbreviations: AICA, anterior inferior cerebellar artery; BA, basilar artery hidden under the right cerebellar hemisphere and brain stem; Clip, blade of Sugita's long aneurysmal clip; Dome, aneurysmal dome including the basilar artery; IX, ninth nerve; It VA, left vertebral artery hidden under the right cerebellar hemisphere and brain stem; mAICA, meatal portion of the anterior inferior cerebellar artery; pAICA, proximal portion of anterior inferior cerebellar artery; $P$ bone, petrous bone; perf $A$, perforating artery; rt VA, right vertebral artery; rup $\mathrm{P}$, rupture point; VII VIII, seventh and eighth nerve complex. 
sectomy. Intraoperatively, we applied a temporary clip to the right vertebral artery. After exposing the aneurysm, we temporarily inflated the occlusion balloon within the left vertebral and right internal carotid arteries to prevent a premature rupture and to facilitate further dissection of the aneurysm. We did not perform systemic heparinization since we expected the duration of the occlusion to be short.

After performing suction decompression from the left vertebral artery, we clipped the neck parallel to the basilar trunk using Sugita's large clip (Fig. 3B). Since the anterior inferior cerebellar artery originated from the lower end of the aneurysmal dome, we performed the clipping so as to spare this artery with a residual dome. The duration of the right internal carotid artery occlusion using the temporary balloon was 90 seconds and that of the left vertebral artery, 105 seconds. Bradycardia occurred 60 seconds after occlusion of the bilateral vertebral arteries and the right internal carotid artery. However, the heart rhythm recovered immediately after the recanalization of these arteries.

Intraoperative digital subtraction angiography, performed just after the clipping, showed obliteration of the aneurysm and preservation of the patency of the basilar and anterior inferior cerebellar arteries (Fig. 2B). After surgery, the patient was in a persistent comatose state for 10 hours. His consciousness level recovered gradually and there were no postoperative deficits attributable to the temporary occlusion, to a distal embolism, or to vessel catheterization.

A postoperative computed tomography scan showed no brain infarction. A tracheostomy and tube feeding were needed for apnea caused by vocal cord paresis and dysphagia. His cough reflex was preserved but his gag reflex was lost. He had no hypesthesia of his face or extremities or paresis of the trigeminal, facial, spinal accessory, and hypoglossal nerves. When he changed hospitals, he had a clear sensorium without paresis of the extremities and he could walk about 5 steps within parallel bars. A follow-up angiography has not yet been performed. However, we consider it mandatory to check for regrowth of the fusiform aneurysm.

\section{Discussion}

Even in a large basilar fusiform aneurysm, it is possible to directly clip the eccentric aneurysmal dome. ${ }^{5(6)}$ In one report, angled clips were applied sequentially to an aneurysm and the basilar artery was successfully reconstructed ${ }^{5}$. However, the direction of clipping tends to be in the same direction as the operative approach. Therefore, the operative approach should be parallel to and must not sacrifice the basilar artery. The conventional retromastoid suboccipital approach was just parallel to the basilar artery in our patient. The elongated aneurysmal dome deviated to the right side and the wide operative space, which resulted from age-related cerebellar atrophy, allowed an excellent access to the basilar trunk.

Nevertheless, there is considerable technical difficulty in gaining proximal artery control. The intraoperative endovascular technique using temporary balloon occlusion can contribute to proximal artery control ${ }^{4}$. Clipping of the tense aneurysm is much easier using suction decompression from the parent artery. Postoperative deficits attributable to the temporary occlusion can occur, so the duration of the temporary balloon occlusion should be as short as possible. ${ }^{4)}$ Intraoperative digital subtraction angiography can also verify the patency of the basilar artery.

Other treatment modalities exist. Stent-assisted coil embolization is an attractive option for fusiform aneurysms. However, recanalization is observed up to 3 years after the initial obliteration. ${ }^{8}$ The Pipeline embolization device (Chestnut Medical, Menlo Park, CA) can achieve complete aneurysmal occlusion without embolization coils and therefore may be used safely in vascular segments that give rise to eloquent perforators. ${ }^{2)}$ Extracranial-intracranial bypass surgery also has been attempted for treating the spontaneous thrombosis of a giant fusiform aneurysm.

\section{References}

1) Bowles AP, Kinjo T, Al-Mefty O: Skull base approaches for posterior circulation aneurysms. Skull Base Surg 5: 251-260, 1995

2) Fiorella D, Kelly ME, Albuquerque FC, Nelson PK, et al: Curative reconstruction of a giant midbasilar trunk aneurysm with the pipeline embolization device. Neurosurgery 64: 212-217, 2009

3) Haque R, Kellner C, Solomon RA: Spontaneous thrombosis of a giant fusiform aneurysm following extracranialintracranial bypass surgery. J Neurosurg 110: 469-474, 2009

4) Mizoi K, Yoshimoto T, Takahashi A, et al: Direct clipping of basilar trunk aneurysms using temporary balloon occlusion. J Neurosurg 80: 230-236, 1994

5) Motoyama Y, Ohnishi H, Koshimae N, et al: Direct clipping of a large basilar trunk aneurysm via the posterior petrosal (extended retrolabyrinthine presigmoid) 
approach--case report. Neurol Med Chir (Tokyo) 40: 632636, 2000

6) Seifert V: Direct surgery of basilar trunk and vertebrobasilar junction aneurysms via the combined transpetrosal approach. Neurol Med Chir (Tokyo) 38 Suppl: 86-92, 1998

7) Taki W, Nakahara I, Sakai N, et al: Large and giant middle to lower basilar trunk aneurysms treated by surgical and interventional neuroradiological methods. Neurol Med Chir (Tokyo) 38: 826-835, 1998

8) Wakhloo AK, Mandell J, Gounis MJ, et al: Stent-assisted reconstructive endovascular repair of cranial fusiform atherosclerotic and dissecting aneurysms: long-term clinical and angiographic follow-up. Stroke 39: 3288-3296, 2008

\author{
要旨 \\ Endovascular technique を用い clipping に成功した, \\ くも膜下出血で発症した脳底動脈の large fusiform aneurysm の 1 例 \\ 雄山 博文, 服部 健一, 鬼頭 晃, 槇 英樹, 棚橋 邦明 \\ 大垣市民病院 脳神経外科
}

症例は 80 歳男性で, 右前下小脳動脈遠位部の脳底動脈本幹 lower portionに発生した large fusiform aneurysmを認めた. 術前に左椎骨動脈と右内澒動脈をバルーンにて確保し, 右後頭下 開頭にて手術を行った。手術時はまず右椎骨動脈に temporary clip を apply し, ついで右内頚動脈と左椎骨動脈を balloon occlusionし, さらに左椎骨動脈より suction decompression を行い動 脈瘤を減圧したうえで, Sugitaのlong clipにて脳底動脈に並行 に clipping を行った. clipping 後すぐ, 術中 DSAにて脳底動脈 の patency と動脈瘤の残存を確認した。覚醒に 10 時間を要し下
部脳神経麻痖を残したものの，意識は回復し四肢の麻疩も残さな かった，本手術では遠位側および近位側の全血管を手術中に確保 することは不可能であり, 術前に術中到達不可能な血管をバルー ンにて確保すべきである.手術時に動脈瘤が緊満しそのままでは clipping できないことが多く，動脈瘤を trapしさらに suction decompression を行い, 動脈瘤を減圧した上で clipping を行わざ るを得ないが，脳虚血を鑑み閉塞時間は最短にすべきである。ま たアプローチの方向にまっすぐに clip をかけざるを得ないことが 多く, 脳底動脈となるべく並行な方向でアプローチすべきである. 